\title{
An Ordered Notl Fragment Map of Human Chromosome Band 11p15
}

\author{
M. J. Higgins, ${ }^{1, *}$ N. J. Smilinich, ${ }^{1}$ S. Sait, ${ }^{1}$ A. Koenig, ${ }^{2}$ J. Pongratz, ${ }^{2}$ M. Gessler, ${ }^{2,3}$ \\ C. W. RICHARd III, ${ }^{4}$ M. R. JAMES, ${ }^{5}$ J. P. SANFORd, ${ }^{1}$ B.-W. KIM, ${ }^{1}$ J. CATTELANE, ${ }^{i}$ N. J. NOWAK, ${ }^{1}$ \\ A. Winterpacht, ${ }^{6}$ B. U. Zabel, ${ }^{6}$ D. J. Munroe, ${ }^{7}$ E. Bric, ${ }^{7}$ D. E. Housman, ${ }^{7}$ \\ C. Jones, ${ }^{8}$ Y. NakAMura, ${ }^{9}$ D. S. Gerhard, ${ }^{10}$ And T. B. Shows ${ }^{1}$ \\ 'Department of Human Genetics, Roswell Park Cancer institute, Buffalo, New York 14263; ${ }^{2}$ Institut für Humangenetik, \\ Phillipps-Universität, D-35037 Marburg. Germany; ${ }^{3}$ Theodor-Boveri-Institut für Biowissenschaften, D-97074 Wuerzburg, \\ Germany: ${ }^{4}$ Department of Psychiatry, University of Pittsburgh, Pittsburgh, Pennsylvania 15213; ${ }^{5}$ INSERM U358 \\ and Centre d'Etude du Polymorphisme Humain, Paris, France; ${ }^{6}$ Universitätkinderklinik Mainz, D-6500, \\ Mainz, Germany; 'Center for Cancer Research, Massachusetts Institute of Technology, Cambridge, \\ Massachusetts 02139; ${ }^{8}$ Eleanor Roosevelt Institute, Denver, Colorado 80262, \\ ${ }^{9}$ Division of Biochemistry, Cancer Institute, Tokyo, Japan; and ${ }^{10}$ Department of Genetics, \\ Washington University School of Medicine, St. Louis, Missouri 63110
}

Received March 28, 1994; revised June 16, 1994

An ordered NotI fragment map containing over 60 loci and encompassing approximately $17 \mathrm{Mb}$ has been constructed for human chromosome band $11 \mathrm{p} 15$. Forty-two probes, including 11 NotI-linking cosmids, were subregionally mapped to $11 \mathrm{p} 15$ using a subset of the J1-deletion hybrids. These and 23 other probes defining loci previously mapped to 11 p15 were hybridized to genomic DNA digested with NotI and 5 other infrequently cleaving restriction enzymes and separated by pulsed-field gel electrophoresis. Thirty-nine distinct NotI fragments were detected encompassing approximately $85 \%$ of the estimated length of $11 \mathrm{p} 15$. The predicted order of the gene loci used is cenMYOD1-PTH-CALCA-ST5-RBTN1-HPX-HBB-RRM1TH/INS/IGF2-H19-CTSD-MUC2-DRD4-HRAS-RNHtel. This map will allow higher resolution mapping of new 11 p15 markers, facilitate positional cloning of disease genes, and provide a framework for the physical mapping of $11 \mathrm{p} 15$ in clone contigs. 1994 Academic Press, Inc.

\section{INTRODUCTION}

Chromosome band $11 \mathrm{p} 15$ covers an estimated $20 \mathrm{Mb}$ of DNA, contains an unusually high number of mapped genes ( 11 p 15.5 in particular), is very GC-rich, and, similar to other telomeric bands, exhibits a frequency of chiasmata higher than that of more proximal bands (Junien and Van Heyningen, 1991; Holmquist, 1992). This region is associated with a number of disease loci

* To whom correspondence should be addressed at Roswell Park Cancer Institute, Elm and Carlton Streets, Buffalo, NY 14263. Telephone: (716) 845-3582. Fax: (716) 845-8449. and contains two or more genes regulated by genomic imprinting.

Band 11p15 contains genes involved in BeckwithWiedemann syndrome (BWS) and tumor suppression. BWS, an overgrowth and cancer predisposition syndrome (Wiedemann, 1964, 1983), has been mapped to this region by the association of cytogenetic abnormalities such as duplications in the distal part of chromosome 11 (Waziri et al., 1983; Turleau et al., 1984; Aleck et al., 1985) and apparently balanced chromosomal translocations and inversions in BWS patients (Mannens et al., 1991; Norman et al., 1992; Weksberg et al., 1993a; Sait et al., 1994). Linkage analysis (Koufos et al., 1989; Ping et al., 1989) of familial cases of BWS have mapped a disease locus near HRAS, INS, and D11S12, all of which map to 11p15.5. Loss of heterozygosity $(\mathrm{LOH})$ studies of the childhood tumors associated with BWS and their sporadic counterparts demonstrate a consistent loss of alleles in $11 \mathrm{p} 15$, with the shortest region of overlap for rhabdomyosarcoma and Wilms tumor being D11S12 to pter (Scrable et al., 1987; Coppes et al., 1992). Significantly, several adult tumors, including breast cancer and bladder, testicular, and ovarian carcinoma (reviewed in Seizinger et al., 1991), also exhibit LOH in this same region, which has now been named multiple tumor associated chromosome region 1 (MTACR1). Further support for the existence of a tumor (growth) suppressor gene(s) in $11 \mathrm{p} 15$ comes from chromosome transfer experiments in rhabdomyosarcoma and rhabdoid tumor cell lines (Dowdy et al., 1991; Loh et al., 1992; Koi et al., 1993).

Pedigree analysis has mapped three other disease loci to chromosome band 11p15. Long QT, characterized by ventricular arrhythmias resulting in recurrent fainting and sudden death, has been genetically linked 
to HRAS in 11p15.5 (Keating et al., 1991). Usher syndrome 1C (deafness, vestibular dysfunction, and progressive pigmentary retinopathy) and familial hyperinsulinism exhibit close genetic linkage with markers in 11p14-p15.1 (Smith et al., 1992; Glaser et al., 1994).

An increasingly large body of evidence indicates that genomic imprinting is operating in $11 \mathrm{p} 15$. For BWS, several observations support this conclusion (reviewed in Puech et al., 1992). For example, expression of the disease appears to be determined by the sex of the transmitting parent, as evidenced by an excess of female carriers in familial BWS (Koufos et al., 1989) and several examples of the transmission of $11 \mathrm{p} 15$ translocations and inversions to affected offspring from phenotypically normal mothers (Mannens et al., 1991; Norman et al., 1992; Christian et al., 1993; Weksberg et al., 1993a). Furthermore, uniparental disomy for $11 \mathrm{p} 15.5$ markers has been demonstrated in some sporadic cases of BWS (Henry et al., 1991). While other explanations exist, the specific loss of maternal 11p15 alleles in pediatric tumors is also consistent with genomic imprinting (Seizinger et al., 1991). Genomic imprinting has been implicated in HLA-DR4-dependent diabetes susceptibility (Julier et al., 1991), a condition that maps at or very close to the INS/GGF2 locus. Two 11 p15.5 genes, IGF2 and H19, have been shown to be oppositely imprinted (Zhang and Tycko, 1992; Giannoukakis et al., 1993; Ogawa et al., 1993; Ohlsson et al., 1993; Rainier et al., 1993). Disruption of the imprinting of IGF2, and perhaps $\mathrm{H} 19$, has been demonstrated in BWS patients and in Wilms tumor (Weksberg et al., 1993b; Ogawa et al., 1993; Rainier et al., 1993). It remains to be shown whether additional genes in $11 \mathrm{p} 15$ exhibit monoallelic expression.

To identify and to clone genes involved in the diseases described above and to characterize and to study a genomic imprinted domain in humans, high-resolution maps of $11 \mathrm{p} 15$ are needed. Positional cloning of disease loci can benefit from a variety of $11 \mathrm{p} 15$ maps. A large number of new polymorphic markers have recently been identified (Takiia et al., 1992; Weissenbach et al., 1992; Couillin et al., 1994), which will facilitate the construction of a high-resolution genetic map (O'Rahilly et al., 1992; NIH/CEPH Collaborative Mapping Group, 1992; Litt et al., 1993; Gyapay et al., 1994). Large numbers of other probes have been generated and mapped within $11 \mathrm{p} 15$, and ordered clone maps are under way (Glaser et al., 1989; Harrison-Lavoie et al., 1989; Newsham et al., 1991; Heding et al., 1992; Puech et al., 1992). Most recently, a high-resolution radiation hybrid map has been constructed for the region (Richard et al., 1993; James et al., 1994). We have developed an ordered NotI restriction fragment map of $11 \mathrm{p} 15$. The map consists of 39 NotI fragments encompassing close to $17 \mathrm{Mb}$ of DNA and contains over 60 loci. The high-resolution framework provided by this map will allow expedient localization of new markers and will facilitate the positional cloning of disease genes in the region.

\section{MATERIALS AND METHODS}

Cell lines. GM00131 and GM07048 are normal human lymphoblastoid cell lines. GM00131 was used as a human control on hybrid mapping panels, while GM07048 served as the standard DNA source for pulsed-field gel electrophoresis (PFGE). Several other human lymphoblastoid (LiDa, GM01484), fibroblast (GM02718, GM02971, GM04250, GM06419), and tumor (RD, AG73, A204) cell lines were used to provide restriction site methylation variability for PFGE analysis (e.g., Fig. 5). Cell lines with names prefaced with GM were obtained from the NIGMS Human Genetic Mutant Cell Repository (Camden, NJ). RD, AG73, and A204 were purchased from the American Type Culture Collection (ATCC) (Rockville, MD). Ten hybrid cell lines from the J1-deletion panel (Kao et al., 1976) contain progressively smaller segments of 11p15 (Glaser et al., 1989).

DNA probes. The probes used in this study were obtained from a variety of sources (Table 1). For H19 a probe was prepared by PCR using primers designed from published sequences (Richard et al. 1993). This probe was also used to retrieve a cosmid from the chromosome 11 library LA11NC01 (L. Deaven, Los Alamos National Laboratory), fragments of which were also used as H19 probes. cDNA30A and cDNA49C are cDNA clones identified in a brain frontal cortex library with cloned exons. These exons, as well as exon $34 \mathrm{C}$, were isolated (D.J.M., unpublished results) using the exon amplification method of Buckler et al. (1991).

Notl-linking cosmids were identified using NotI end-clones constructed from hybrid J1-11 (A.K., J.P., M.G., unpublished). Inserts from pools of NotI-end phage clones mapping to $11 \mathrm{p} 15$ were hybridized to the arrayed chromosome 11 cosmid library. DNA from individual positive cosmids was digested with EcoRI, NotI, and EcoRI plus NotI to identify overlapping cosmids containing the same NotI site(s) EcoRI fragments cleaved by NotI were excised from low-melting. point agarose gels, radiolabeled by random priming (Feinberg and Vogelstein, 1983) and hybridized to Southern blots of EcoRI and EcoRI/NotI digests of genomic DNA to confirm that the NotI site(s) in the cosmids was cleaved in the genome.

Hybrid panel analysis. Genomic DNA $(5 \mu \mathrm{g})$ from the J1-series cell lines, human (GM00131) and hamster (CHW1102), was digested with EcoRI or HindIII (New England Biolabs) using the buffers supplied. Following overnight electrophoresis in $0.8 \%$ agarose, gels were transferred to GeneScreen Plus (NEN-Dupont) under conditions recommended by the manufacturer. Hybridization was carried out in 1 $M \mathrm{NaCl}, 1 \% \mathrm{SDS}, 10 \%$ dextran sulfate (Pharmacia), and $150 \mu \mathrm{g} / \mathrm{m}$ denatured salmon sperm DNA using DNA probes labeled by random priming. Labeled DNA fragments containing repetitive sequences were precipitated with ethanol, redissolved in $7.5 \mathrm{mg} / \mathrm{ml}$ human placental DNA in $5 \times \mathrm{SSC}(1 \times \mathrm{SSC}$ is $0.15 \mathrm{M} \mathrm{NaCl} / 0.015$ sodium citrate, $\mathrm{pH} \mathrm{7.0)}$, boiled for $5 \mathrm{~min}$, and preannealed for $15 \mathrm{~min}$ at $65^{\circ} \mathrm{C}$

Pulsed-field gel analysis. High-molecular-weight DNA from GM07048 (and other cell lines in some cases, e.g., Fig. 5) was prepared in agarose plugs from cells suspended in phosphate-buffered saline $\left(10^{7}\right.$ cells per $\left.\mathrm{ml}\right)$ as described (Higgins et al., 1989). Restriction enzyme digests were carried out under the buffer conditions recommended by the supplier (New England Biolabs) except that spermidine was added (to a final concentration of $5 \mathrm{mM}$ ) to buffers with $>50$ $\mathrm{mM} \mathrm{NaCl}$. To ensure complete digestion with a minimum amount of enzyme, digests were set up by combining all reaction components on ice and maintaining the reaction mixtures overnight at $4^{\circ} \mathrm{C}$ before incubation at the appropriate temperature for $90 \mathrm{~min}$. Restriction digests were routinely done using 7 units enzyme/ $\mu$ g DNA, except with $S g r A I$, which was used at 4 units/ $\mu$ g DNA.

Pulsed-field electrophoresis was carried out using either a CHEFDRII (BioRad, Inc.) or a one-dimensional PFGE system as described previously (Lalande et al., 1987). CHEF gels were $1 \%$ agarose in $0.5 \times$ TBE (1X TBE is $89 \mathrm{mM}$ Tris-borate/ $89 \mathrm{mM}$ boric acid/2 mM EDTA, pH 8.3). CHEF gel switching conditions were $8 \mathrm{~s}(22 \mathrm{~h}, 200$ V) for small fragments up to $200 \mathrm{~kb}$, a 10 - to 50 -s ramp ( $29 \mathrm{~h}, 200$ V) for fragments of 20 to $700 \mathrm{~kb}$, and $60 \mathrm{~s} \mathrm{(17} \mathrm{h,200} \mathrm{V)} \mathrm{followed} \mathrm{by}$ $100 \mathrm{~s}(12 \mathrm{~h}, 200 \mathrm{~V})$ for a wide range of separation from 20 to 1100 kb. For analysis of very large restriction fragments (i.e., $>1000 \mathrm{~kb}$ ), 


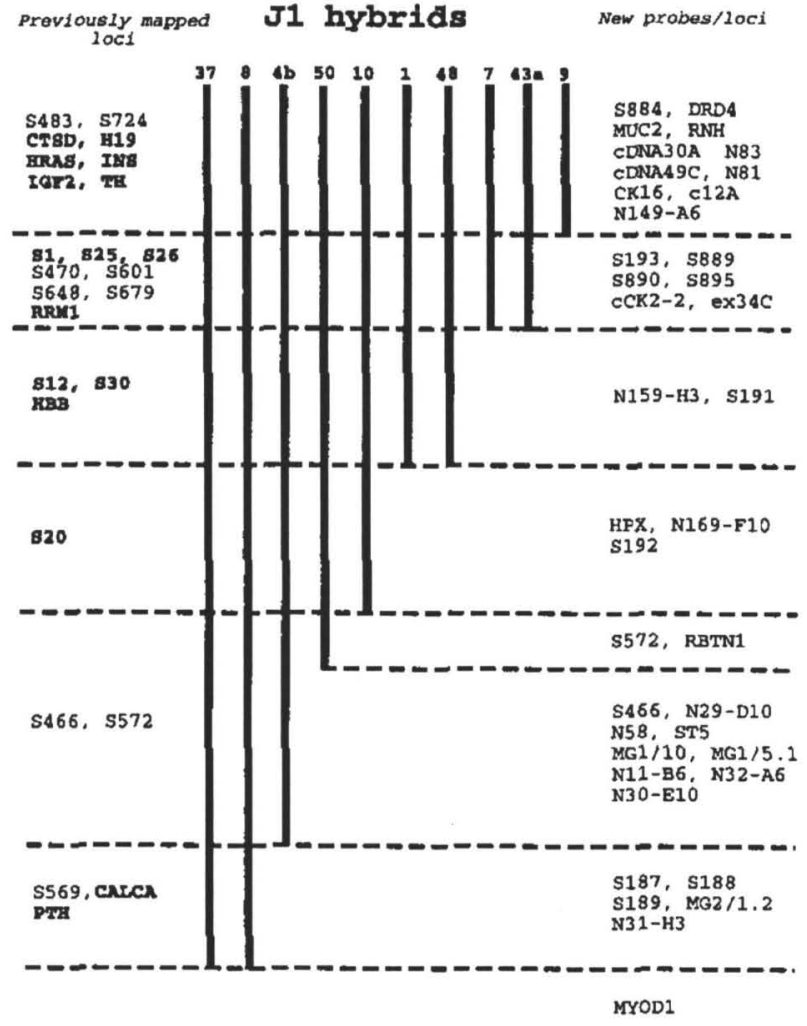

FIG. 1. The $10 \mathrm{~J} 1$ hybrids used in this study are shown schematically with their $11 \mathrm{p} 15$ content indicated by the heavy vertical lines. The loci shown to the left in boldface are those used in the original characterization of the J1 hybrids (Glaser et al., 1989) with the remainder being those mapped by Tanigami et al. (1992). The new loci mapped using the $J 1$ hybrids, as well as the additional mapping interval defined with $\mathrm{J} 1-50$, are shown to the right of the figure.

either CHEF gels were used at 120 and $180 \mathrm{~s}$ for $22 \mathrm{~h}$ each at 150 V or the one-dimensional PFG apparatus was used with switching times varying between 75 and $3000 \mathrm{~s}$ as described (Higgins et al., 1990). Transfer of pulsed-field gels to nylon membranes and hybridization were as described above, except that before denaturation the gels were nicked for $90 \mathrm{~s}$ on a UV transilluminator.

Interphase fluorescence in situ hybridization. Interphase mapping was carried out on foreskin fibroblast cultures (GM08333) using the methods of Trask et al. (1991) and Flejter et al. (1993) with minor modifications.

\section{RESULTS}

Mapping using the $\mathrm{J} 1$ hybrids. The J1 series of deletion hybrids (Kao et al., 1976) were used to establish the first physical orientation of known genes and anonymous DNA markers in chromosome band 11p15 (Glaser et al., 1989). The 10 members of this hybrid panel used in the present study are shown in Fig. 1, with markers used in the original characterization indicated in boldface. With the exception of D11S20, each of the loci shown to the left in Fig. 1 has been included in the long-range mapping (see below). Originally this subset of $\mathrm{J} 1$ hybrids subdivided $11 \mathrm{p} 15$ into five distinct map intervals (Glaser et al., 1989). Some of these same hybrids have been used to group several cosmids in $11 \mathrm{p} 15$ (Tokino et al., 1991), two of which (D11S466 and D11S572) defined an additional interval between the breakpoints of J1-10 and J1-4b (Tanigami et al., 1992).

We have used this set of hybrids to map more than 40 additional 11 p15 markers (Fig. 1). For example, a probe for DRD4 hybridized to each member of the set, localizing it to the most distal interval with several other genes, including IGF2 and HRAS. A probe (pCRT21) for the RBTN1 gene hybridized to J1-37, J18, J1-4b, and J1-50 (but not to J1-10). This result localizes this locus to the same interval as D11S572, proximal to HPX, and demonstrates that J1-50 (like J1-4b) extends proximally farther than $\mathrm{J} 1-10$ (Fig. 1). The inclusion of J1-50 in the mapping panel located D11S466 (which is negative in this hybrid) proximal to RBTN1 and D11S572 into a new interval containing several loci, including ST5. The localization for the remainder of loci mapped using this subset of $\mathrm{J} 1$ hybrid is summarized in Fig. 1.

Long-range restriction mapping. A total of 65 probes (Table 1) for anonymous DNA segments, NotIlinking clones, and gene sequences were included in the pulsed-field gel analysis of p15. In general, each probe was hybridized to GM07048 DNA digested with NotI and five other infrequently cleaving restriction enzymes (Table 2). Double digests with Not I in combination with the other enzymes were not performed; however, results from other restriction digests provided confirmation of physical linkage, order information, and, in some cases, maximum distances between NotI fragments.

Initially, each probe was hybridized to Southern blots prepared from CHEF gels run under "standard" conditions chosen to separate a wide range of DNA fragments from 20 to $\sim 1100 \mathrm{~kb}$. Probes detecting restriction fragments less than $200 \mathrm{~kb}$ long were also hybridized to the same digests electrophoresed in an " $8 \mathrm{~s}$ " CHEF gel, which gave much higher resolution in the 10 - to $200-\mathrm{kb}$ range. If no distinct band was observed for a given probe in one or more restriction digests run in the "standard" CHEF, or if there was obvious hybridization at the compression zone, then the marker was also hybridized to Southern blots prepared from CHEF gels run at 120 - and 180 -s switch times or one-dimensional pulsed-field gels (see Materials and Methods), which separated DNA fragments up to $6000 \mathrm{~kb}$.

When establishing physical linkage, a number of criteria were observed to distinguish between identical and comigrating nonidentical restriction fragments. For example, if two loci are suspected to be physically linked based on commonality of restriction fragments, then they must be in the same or adjacent hybrid map intervals. In general, two loci were considered physically linked when their respective probes detected common fragments generated by at least two restriction 
TABLE 1

Probes Used in Pulsed-Field Gel Analysis

\begin{tabular}{|c|c|c|}
\hline Probe name & Locus & Source/reference \\
\hline pT24C3 & HRAS & $\mathrm{ATCC}^{a}$ \\
\hline phins214 & INS & ATCC \\
\hline phins311 & IGF2 & ATCC \\
\hline pHGTH4 & TH & ATCC \\
\hline pE1.8 & RRM1 & ATCC \\
\hline pADJ762 & $\mathrm{D} 11 \mathrm{~S} 12$ & ATCC \\
\hline pMyf3 & MYOD1 & ATCC \\
\hline $\mathrm{p} 20.36$ & PTH & ATCC \\
\hline D11RP633 & D11S187 & Davis et al. (1988) \\
\hline D11RP789 & $\mathrm{D} 11 \mathrm{~S} 188$ & Davis et al. (1988) \\
\hline D11RP890 & D11S189 & Davis et al. (1988) \\
\hline D11RP1030 & D11S191 & Davis et al. (1988) \\
\hline D11RP1038 & D11S192 & Davis et al. (1988) \\
\hline D11RP1051 & D11S193 & Davis et al. (1988) \\
\hline pCS1 & D11S1 & Glaser et al. (1989) \\
\hline $\mathrm{p} \gamma 6$ & D11S25 & Glaser et al. (1989) \\
\hline pGGE0.9 & D11S26 & Glaser et al. (1989) \\
\hline pJ1.1 & D11S30 & Glaser et al. (1989) \\
\hline $\mathrm{pSP} \beta \mathrm{c}$ & $\mathrm{HBB}$ & L. Maquat, RPCI \\
\hline p1215 & $\mathrm{HBB}$ & P. Dierks, U. of Vermont \\
\hline pTT24 & CALCA & $\begin{array}{l}\text { B. Nelkin, Johns Hopkins } \\
\text { University }\end{array}$ \\
\hline pCD2.1EX & CTSD & J. Chirgwin, U. of Texas \\
\hline $\mathrm{cC} 4\left(76 \mathrm{H}^{b}\right)$ & CTSD & $\begin{array}{l}\text { B. Weissman, U. of North } \\
\text { Carolina }\end{array}$ \\
\hline p1596 & ST5 & $\begin{array}{l}\text { J. Licky, Department of } \\
\text { Defense }\end{array}$ \\
\hline $\mathrm{pHPX}$ & HPX & F. Altruda, U. of Torino \\
\hline Clone 20 & DRD4 & $\begin{array}{l}\text { H.H.M. Van Tol, Clarke } \\
\text { Institute }\end{array}$ \\
\hline $\mathrm{cM} 4\left(83 \mathrm{~B} 11^{b}\right)$ & MUC2 & $\begin{array}{l}\text { B. Weissman, U. of North } \\
\text { Carolina }\end{array}$ \\
\hline cI11-280 & D11S466 & JCRRB $^{\mathrm{c}}$ \\
\hline cI11-289 & D11S470 & JCRRB \\
\hline cI11-330 & D11S483 & JCRRB \\
\hline cI11-434 & D11S569 & JCRRB \\
\hline cI11-440 & D11S572 & JCRRB \\
\hline cI11-555 & D11S764 & JCRRB \\
\hline cI11-565 & D11S601 & JCRRB \\
\hline N81, N83 & - & Sanford et al. (1993) \\
\hline pRAI & $\mathrm{RNH}$ & Schneider et al. (1988) \\
\hline $\mathrm{pB} 2, \mathrm{pCRT} 21$ & RBTN1 & UK DNA Probe Bank \\
\hline $\mathrm{MG} 1 / 5.1,1 / 10,2 / 1.2$ & - & $\begin{array}{l}\lambda \text {-clones selected with } 11 \mathrm{p} 15.5, \\
\text { microdissection library }\end{array}$ \\
\hline CK16 & - & $\begin{array}{l}\text { Alu-PCR clone, B.W.K. } \\
\text { unpublished }\end{array}$ \\
\hline CR133 & D11S884 & Richard et al. (1993) \\
\hline CR149 & D11S889 & Richard et al. (1993) \\
\hline CR154 & D11S890 & Richard et al. (1993) \\
\hline CR179 & D11S895 & Richard et al. (1993) \\
\hline H19-PCR & H19 & Richard et al. (1993) \\
\hline $\mathrm{cH} 19$ & $\mathrm{H} 19$ & See Materials and Methods \\
\hline $\begin{array}{l}\text { cDNA30A, } 49 \mathrm{C} \text {, and } \\
\text { exon } 34 \mathrm{C}\end{array}$ & - & See Materials and Methods \\
\hline $\begin{array}{l}\text { NotI-linking } \\
\text { cosmids }^{e}\end{array}$ & - & See Materials and Methods \\
\hline
\end{tabular}

a American Type Tissue Collection (Rockville, MD)

${ }^{b}$ Plate and coordinate number in the arrayed chromosome 11 cosmid library LA11NC01 (L. Deaven, Los Alamos National Laboratory; G. Evans, Salk Institute)

c Japanese Cancer Research Resources Bank (Tokyo).

${ }^{d}$ Microdissection library provided by U. Claussen and B. Horsthemke (U. of Essen).

' Not1-linking clones are designated by the plate and coordinate number (prefaced by the letter $N$ ) in the arrayed cosmid library. endonucleases. When possible, identity of restriction fragments was confirmed by using the same blot for the two probes in question. Probes for loci on the same restriction fragment should detect similar or complementary patterns of methylation or polymorphism-induced change in size or intensity.

Fragment sizes for each of the loci analyzed are compiled in Table 2. Thirty-nine distinct NotI fragments were detected with a combined length of almost 17,000 $\mathrm{kb}$. The length of the fragments varied widely from 20 to $2500 \mathrm{~kb}$. Although gaps exist, in many cases commonality of restriction fragments generated by other enzymes established physical linkage of loci on different NotI fragments. Using the hybrid mapping data and the information in Table 2, an ordered Not I restriction fragment map of $11 \mathrm{p} 15$ has been constructed (Fig. 2 ). The following is a description of some of its features.

The MYOD1 / PTH/CALCA region. Although MYOD1 has been mapped to $11 \mathrm{p} 14.3-\mathrm{p} 15.1$ (Gessler et al., 1990; Henry et al., 1993), it was not present in either $J 1-8$ or J-37, making it the most centromeric marker on the map. DNA probes for eight loci within the interval defined by hybrid J1-4b and hybrid pair J1-8/37 detected five different NotI fragments (Fig. 2A). NotIlinking cosmid N31-H3 detected both the 280 -kb fragment detected by MG2/1.2 and the 2500-kb fragment carrying CALCA and D11S188. This linkage was verified using other restriction enzymes (Table 2) and provides the only confirmed physical connection between loci in this interval. D11S189 is contained in two independent radiation hybrids that are positive for all distal loci tested (i.e., RBTN1, HBB, D11S12, IGF2, and HRAS) but negative for CALCA, PTH, and MYOD1 (unpublished results), positioning this locus distal to CALCA and PTH. D11S569 has also been located distal to CALCA and PTH by radiation hybrid mapping (James et al., 1994). A tentative linkage between D11S189, D11S569, and CALCA through a 2300-kb AscI fragment supports the placement of CALCA telomeric to PTH (Henry et al., 1989; O'Rahilly et al., 1992).

The RBTN1/ST5 gene region. A number of probes, including four new NotI-linking loci, mapped into the region containing the RBTN1 and ST5 genes by virtue of their being positive in J1-4b and negative in J1-10. Of these, only D11S572 was contained in J1-50 with RBTN1 (Fig. 1). Since J1-50 was a difficult hybrid to use (because only a small proportion of cells contained human DNA), each probe in the $\mathrm{J} 1-4 \mathrm{~b}$ to $\mathrm{J} 1-10$ interval was also tested with somatic cell hybrids segregating the der(11) and der(14) chromosomes of a T-cell leukemia $t(11 ; 14)$, the chromosome 11 breakpoint that defined the RBTN1 gene (Boehm et al., 1988). D11S572 segregated with the telomeric probe for RBTN1, while the remainder of the loci segregated with the centromeric RBT'N1 probe (data not shown), thus confirming that RBTN1 and D11S572 are distal to the other loci in this interval.

Cosmid cDI11-280 (D11S466) detected 260- and 350- 
TABLE 2

Restriction Fragments Containing 11p15 Loci

\begin{tabular}{|c|c|c|c|c|c|c|c|c|c|c|c|c|c|}
\hline Locus & NotI & $A s c \mathrm{I}$ & BssHI & SgrAI & MluI & NruI & Locus & NotI & $A s c \mathrm{I}$ & Bss HI & SgrAI & MluI & Nrul \\
\hline \multirow[t]{2}{*}{ MYOD } & 40 & ND & 20 & 350 & 40 & 680 & D11S25 & 600 & 440 & 175 & 330 & 190 & 200 \\
\hline & 550 & & & 400 & 280 & & D11S26 & 850 & & & 525 & 320 & 400 \\
\hline PTH & 730 & 2100 & 730 & ND & 730 & 260 & D11S470 & & & & 650 & 660 & \\
\hline \multirow[t]{2}{*}{ D11S18? } & & & & & 1150 & & cCK2-2 & & & & 1100 & & \\
\hline & & & & & 1600 & & D11S890 & 170 & 160 & 170 & 170 & 160 & 680 \\
\hline CALCA & 2500 & 2300 & 100 & 1800 & 100 & 1400 & D11S601 & 80 & 280 & $60+$ & 480 & & 1060 \\
\hline D11S188 & & & & 2200 & & 2200 & & & 725 & & & & \\
\hline \multirow[t]{2}{*}{ N31-H3 } & 2500 & 2300 & 290 & 1800 & 650 & 1400 & D11S193 & 60 & 280 & 60 & 170 & 160 & 680 \\
\hline & 280 & & 250 & 22000 & & 2200 & D11S895 & & 725 & & 480 & & 1060 \\
\hline D11S569 & 280 & 2900 & 2501 & 1800 & 650 & 400 & Exon 34c & & & & & & \\
\hline \multirow{4}{*}{ D11S189 } & 650 & 2300 & 320 & 500 & ND & 1000 & D11S648 & 35 & 280 & 35 & 20 & 160 & 680 \\
\hline & 1050 & 2300 & 800 & 1400 & 1125 & 630 & & & 725 & 240 & & & 1060 \\
\hline & & & & & & 700 & D11S1 & 160 & 280 & 45 & 100 & 470 & 680 \\
\hline & & & & & & 1125 & D11S679 & 180 & 725 & 90 & 200 & 560 & 1060 \\
\hline N30-E10 & 325 & 200 & 140 & 730 & 2300 & 460 & & 680 & & 130 & 360 & & \\
\hline \multirow[t]{2}{*}{ N155-E5 } & 700 & & 485 & & & & & & & & 400 & & \\
\hline & & & 550 & & & & & & & & 450 & & \\
\hline \multirow[t]{2}{*}{ N32-A6 } & 700 & 500 & 220 & 50 & 450 & 600 & D11S724 & 250 & 445 & 200 & 250 & 470 & 680 \\
\hline & 400 & & $\begin{array}{l}450 \\
600\end{array}$ & 650 & 2300 & & & 410 & 725 & 250 & 450 & 550. & 1060 \\
\hline N11-B6 & 400 & 500 & 100 & 100 & 2300 & 900 & 1GF2 & 2800 & 560 & $\begin{array}{r}300 \\
25\end{array}$ & & & \\
\hline \multirow{2}{*}{ N167-C4 } & 100 & & 200 & 300 & 2000 & & INS & 560 & 730 & 115 & $\begin{array}{r}55 \\
115\end{array}$ & $\begin{array}{r}125 \\
260 \\
\end{array}$ & $\begin{array}{r}380 \\
1060 \\
\end{array}$ \\
\hline & & & 450 & 400 & & & TH & & & & 205 & 630 & \\
\hline \multirow{4}{*}{$\begin{array}{l}\text { ST5 } \\
\text { MG1/5.1 } \\
\text { MG1/10 } \\
\text { N58 }\end{array}$} & 260 & 400 & 200 & 600 & 2300 & 900 & D11S884 & & & & 300 & 680 & \\
\hline & & & 260 & 680 & & & & & & & & 780 & \\
\hline & & & & & & & H19 & 280 & 560 & 210 & 140 & 140 & 170 \\
\hline & & & & & & & cDNA30a & 560 & 730 & & 2207 & 380 & 480 \\
\hline \multirow{3}{*}{$\begin{array}{l}\text { D11S466 } \\
\text { N29-D10 } \\
\text { N57-C12 }\end{array}$} & 260. & 400. & 200 & 600 & 2300 & 900 & & & & & 340 & 480 & 650 \\
\hline & 350 & & 260 & 680 & & 460 & & & & & 480 & 630 & \\
\hline & & & & & & & & & & & & 660 & \\
\hline \multirow{2}{*}{$\begin{array}{l}\text { RBTN1 } \\
\text { (B2) }\end{array}$} & 280 & 1000 & 350 & 80 & 2900 & 460. & & & & & & 780 & \\
\hline & & & & 680 & & & CTSD & 325 & 560 & 80 & 80 & 245 & 400 \\
\hline \multirow{2}{*}{$\begin{array}{l}\text { RBTN1 } \\
\text { (CRT21) }\end{array}$} & 280 & 2000 & 200 & 280 & 2300 & 2007 & & & 730. & 245 & 220 & 350 & 480 \\
\hline & & & & & & & & & & & 270 & 380 & 650 \\
\hline D11S572 & 230 & 1000 & 200 & 280 & $\begin{array}{l}195 \\
380\end{array}$ & 200 & & & & & 840 & $\begin{array}{l}480 \\
630\end{array}$ & \\
\hline D11S192 & 780 & 600 & 460 & 1400 & 1100 & 1100 & & & & & 480 & 660 & \\
\hline & & & & & & 1800 & & & & & & 780 & \\
\hline N169-F10 & 790 & 600 & 460 & 1400 & 1100 & 2800 & CK16 & 560 & 1500 & 560 & 975 & 975 & 1200 \\
\hline & 000 & & 730 & & & & & & & & 1100 & 1500 & \\
\hline $\mathrm{HPX}$ & 800 & ND & 120 & 230 & 2200 & 150 & N81 & 130 & 360 & 78 & 150 & 180 & 300 \\
\hline & & & 460 & 1000 & 3400 & 220 & & & 670 & 150 & 175 & 210 & 500 \\
\hline HBB & 2300 & 4000 & 1200 & 450 & 2200 & 370 & & & & & 230 & 250 & \\
\hline & & & & 550 & 3400 & 1300 & N149-A6 & 150 & 360 & 180 & t50 & 180 & 300 \\
\hline & & & & & & 2100 & & 200 & 650 & 100 & 230 & 210 & 500 \\
\hline & & & & & & 3100 & MUC2 & 120 & 290 & 275 & 400 & 240 & 200 \\
\hline D11S30 & $2500=$ & 4000 & 1200 & 1100 & 2200 & 3100 & & 300 & 650 & 400 & & 290 & 440 \\
\hline & & & & & 3400 & & & 400 & & & & 440 & 520 \\
\hline D11S191 & 2300 & 4000 & 1200 & 1100 & 1850 & 2100 & & 570 & & & & & \\
\hline & & & & & 3400 & 8100 & DRD4 & 60 & 85 & 60 & 175 & 180 & 60 \\
\hline N159-H3 & 2300 & $\$ 000$ & 250 & 1200 & 1350 & 1100 & e12A & & & & & & 120 \\
\hline & 390 & & 350 & & 3400 & 1350 & & & & & & & 200 \\
\hline & & & & & & 2100 & HRAS & 30 & 50 & 20 & 75 & & 7 \\
\hline & & & & & & s100 & & 90 & & & & 850 & 25 \\
\hline D11S12 & 390 & $\begin{array}{l}2400 \\
3400\end{array}$ & 850 & 1100 & $\begin{array}{l}470 \\
660\end{array} \mid$ & $\begin{array}{l}1100 \\
7250\end{array}$ & & & & & & $\begin{array}{l}430 \\
320\end{array}$ & \\
\hline & & 4090 & & & 1100 & 2100 & $\mathrm{RNH}$ & 60 & 225 & 60 & 75 & 350 & 350 \\
\hline & & & & & $\begin{array}{l}1350 \\
3400\end{array}$ & 3100 & & 90 & & & & $\begin{array}{l}430 \\
520\end{array}$ & \\
\hline RRM1 & 390 & $\begin{array}{l}3400 \\
4000\end{array}$ & 350 & 1100 & & & $\mathrm{~N} 83$ & 50 & 225 & 40 & 160 & 350 & 350 \\
\hline D11S889 & 390 & 3400 & 350 & 310 & 470 & 2100 & & & & & & $\begin{array}{l}430 \\
520\end{array}$ & \\
\hline & & 4000 & & & 660 & 3100 & D11S483 & 90 & 50 & 50 & ND & 90 & 350 \\
\hline & & & & & $\begin{array}{l}2950 \\
8400\end{array}$ & & eDNA49c & & & & & 430 & \\
\hline
\end{tabular}

Note. The sizes (in kilobases) of restriction fragments detected by $11 \mathrm{p} 15$ probes in Not I, AscI, Bss HII, SgrAI, MluI, and NruI digests are listed. Restriction fragments that establish physical linkage are enclosed in shaded boxes. Linkages defined by only one poorly resolved fragment are shown in open boxes. ND, not determined.

kb NotI fragments, as well as 460- and 900-kb NruI cCI11-280. The two probes used for the RBTN1 locus fragments (Fig. 3A, Table 2). Restriction analysis dem- (pCRT21 and pB2) detect the same NotI, AscI, and onstrated that cCI11-280 is both a NotI and a NruI MluI fragments, but different BssHII and NruI fraglinking clone (not shown). Probes MG1/5.1 (Fig. 3A), ments, suggesting that a CpG-island may exist beMG1/10, N58, and p1596 (ST5) each detected the 260- tween them. The 680-kb SgrAI fragment detected by $\mathrm{kb}$ NotI and 900-kb NruI fragments, as well as several $\mathrm{pB} 2$, the proximal RBTN1 probe, was also detected by other restriction fragments (Table 2) in common with cCI11-280. This physical linkage was supported by a 
A

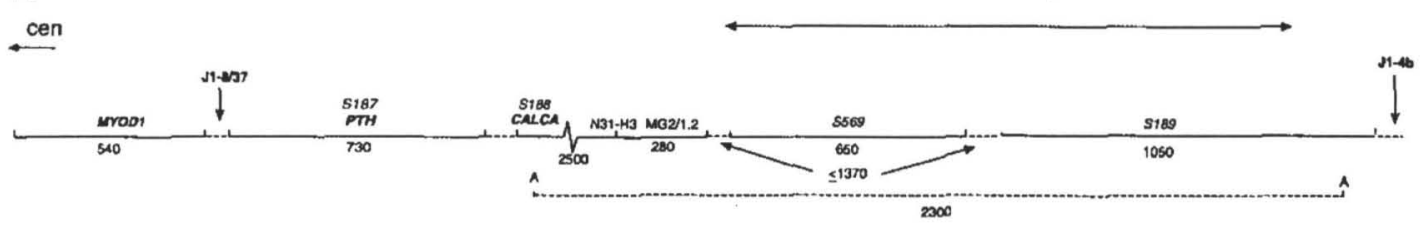

B

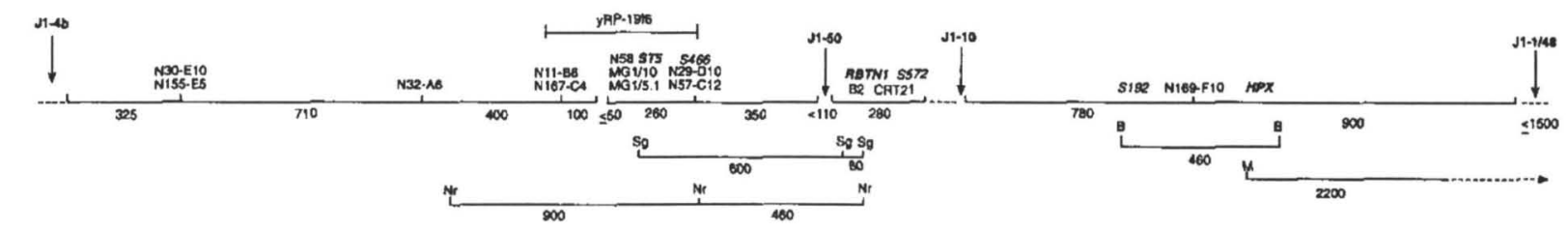

C

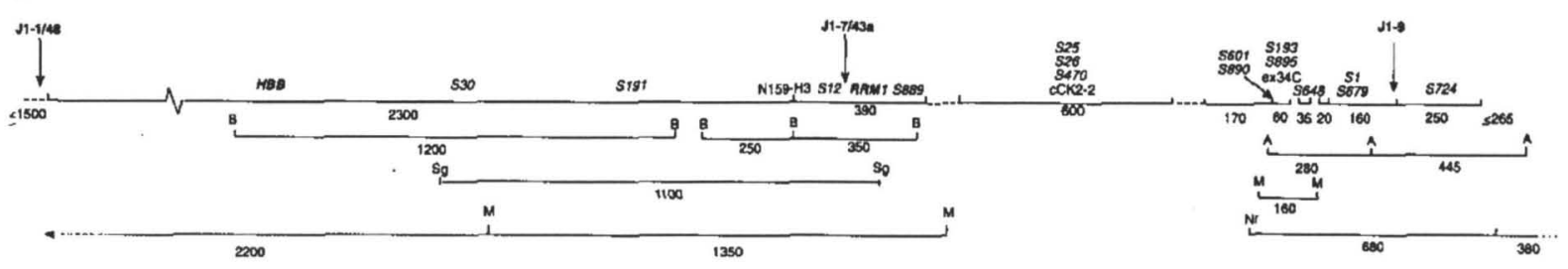

D

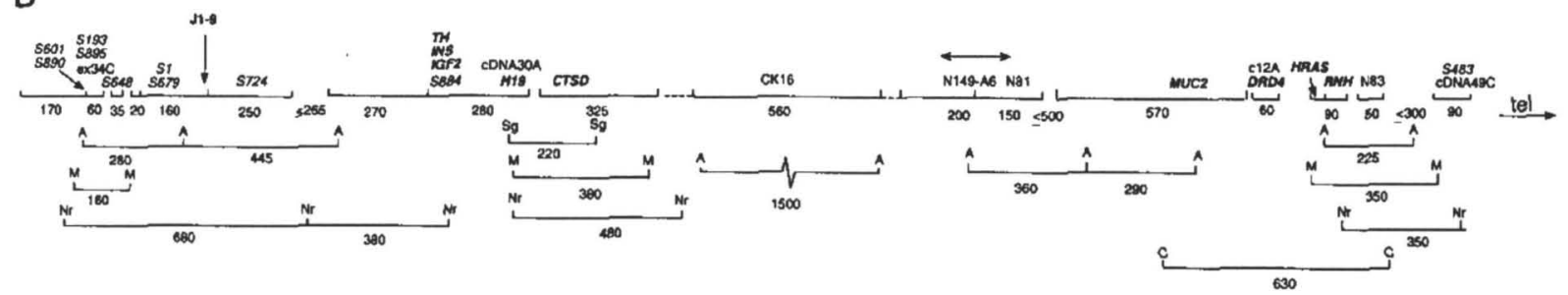

FIG. 2. Ordered $N o t \mathrm{I}$ fragment map of $11 \mathrm{p} 15$. Only the Not $\mathrm{I}$ fragments are shown, except when those fragments generated by other enzymes allow ordering or estimation of genomic distances between NotI fragments. Other enzymes were AscI (A), BssHII (B), ClaI (C), MluI (M), NruI (Nr), and SgrAI (Sg). Probes designated by the letter "S" and then a number indicate D11S loci. The size of each NotI fragment is shown below the line. The 2300-kb AscI fragment connecting CALCAD11S188 and D11S189 is drawn as a dashed line to indicate that physical linkage between these loci is based solely on this single restriction fragment and, therefore, remains tentative. Ambiguity in the order of fragments is indicated by the arrows above the map. The positions of the breakpoints of the J1 hybrids are indicated by the vertical arrows. Their placement is only approximate, and it is not necessarily implied that they disrupt the NotI fragment drawn below. The total length of DNA mapped as NotI fragments is approximately $17 \mathrm{Mb}$ or about $85 \%$ of the estimated length of $11 \mathrm{p} 15$.

460-kb NruI fragment in common between these two loci (Fig. 3) and positions D11S466 and the ST5 gene just centromeric of RBTN1 (Fig. 2B). From this result, the gap between NotI fragments carrying RBTN1 and D11S466 was estimated to be $\leqslant 110 \mathrm{~kb}$. The $900-\mathrm{kb}$ NruI fragment containing D11S466 MG1/5.1, MG1/10, N58, and ST5 was also detected by NotI-linking cosmids N11-B6 and N167-C4 (Table 2). This linkage was confirmed by the finding that probes from N11-B6 and cCI11-280 detected a 400-kb YAC (yeast artificial chromosome) in common (unpublished result). N11-B6 (and
N167-C4) represents one Not I site in a 1535 -kb contiguous map consisting of four NotI fragments just centromeric to the ST5 gene (Fig. 2B) defined entirely by NotI-linking cosmids. No restriction fragments were found in common between N30-E10/N155-E5 and either D11S189 or D11S569, precluding an estimation of the genomic distance separating them.

The HPX gene region. Probes for D11S192, N169$\mathrm{F} 10$, and HPX were positive in $\mathrm{J} 1-10$ but negative in hybrid pair J1-1/48, placing these three loci between RBTN1 and HBB (Fig. 1). The NotI site-containing 


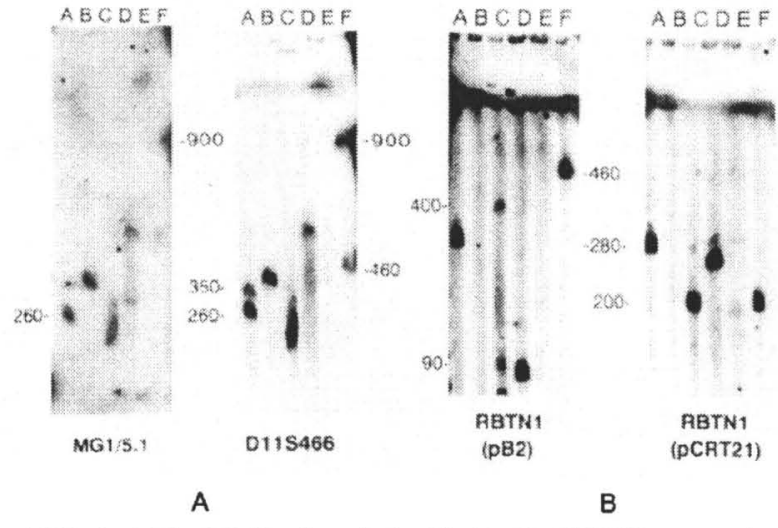

FIG. 3. Pulsed-field gel analysis of loci in the RBTN1 gene region. High-molecular-weight DNA from cell line GM07048 was digested with NotI (lane A), AscI (lane B), BssHII (lane C), SgrAI (lane D), MluI (lane E), and NruI (lane F) and electrophoresed in CHEF gels. Switching times were either $60 \mathrm{~s}$ followed by $100 \mathrm{~s}$ (A) or a 10- to 50-s ramp (B). Following transfer to nylon membranes, the filters were hybridized with probes for the indicated loci. The sizes of selected fragments are in kilobases.

fragment from N169-F10 detected 780- and 900-kb NotI fragments. LL1038 (D11S192) detected the 780$\mathrm{kb}$ Not I fragment and other fragments in common with N169-F10, while a probe for HPX detected the 900-kb NotI fragment and BssHII fragments identified by this NotI-linking cosmid (Table 2). The orientation of these three loci is uncertain; however, tentative linkage of HPX to HBB through two large (2200 and $3400 \mathrm{~kb}$ ) MluI fragments places the $900-\mathrm{kb}$ Not I fragment distal to the $780-\mathrm{kb}$ fragment (Fig. 2B). No physical connections between D11S192, N169-F10, or HPX have been established with D11S572 and RBTN1 in the next centromeric hybrid mapping interval.

The HBB /D11S12 interval. Five loci were positive for hybrid pair J1-1/48 but missing in hybrid pair J17/43a (Fig. 1). Three of these (D11S30, D11S191, HBB) lie on a $2300-\mathrm{kb}$ Not I fragment, while D11S12 was contained on a $390-\mathrm{kb}$ NotI fragment (Fig. 4, Table 2). The NotI-linking fragment from N159-H3 detected both the 2300 - and the $390-\mathrm{kb}$ fragments (Fig. 4), demonstrating that these two NotI fragments are contiguous (Fig. 2C). Several large restriction fragments (AscI, MluI , NruI) appear to be in common between D11S12 and the HBB group of loci (Fig. 4, Table 2). However, HBB does not share a 1100-kb SgrAl fragment in common between D11S12, N159-H3, D11S191, and D11S30, making it the most proximal of these markers. The detection of a 2200-kb MluI fragment by pJ1.1 (D11S30) rather than the 1350-kb MluI fragment detected by LL1030 (D11S191), N159-H3, and pADJ762 (D11S12) positions D11S30 centromeric to the other three loci (Fig. 2C).

The J1-7/43a to J1-9 interval. Eight loci used in this analysis have been mapped previously (Glaser et al., 1989; Tanigami et al., 1992) into the region delimited by the 11p15 breakpoints of J1-7/43a and J1-9 (i.e., between D11S12 and the gene cluster containing
TH, INS, IGF2, CTSD, and H19). Six additional loci have been located in this interval (Fig. 1). Probes for RRM1 and D11S889 hybridized to most of the same restriction fragments as D11S12. Since D11S12 is absent from J1-7/43a, it must be centromeric to RRM1 and D11S889. RRM1 also lies on the 1100-kb SgrAI fragment in common between D11S12, N159-H3, D11S191, and D11S30. Since the probe for D11S889 detects a 310-kb SgrAI fragment instead, it must be telomeric to both RRM1 and D11S12.

The remaining loci in this interval define seven more Not I fragments ranging from 20 to $600 \mathrm{~kb}$ (Fig. 2C). Unexpectedly, probes for four independently cloned loci (D11S25, S26, S470, cCK2-2) detected a 600-kb NotI fragment and exactly the same set of restriction fragments with each of the other enzymes used, the smallest being a 170-kb BssHII fragment. Thus, no order could be inferred. The cosmid cCI11-565 (D11S601) contains restriction sites for NotI, AscI, and BssHII and, typical of linking clones, detects two restriction fragments for each of these enzymes (three in AscI). D11S193, D11S895, and exon 34C are located on the smaller $(60 \mathrm{~kb})$ of the two NotI fragments defined by D11S601. In contrast, pCS1 (D11S1) and cCI11-469 (D11S679) contain none of these restriction sites yet hybridize to three NotI fragments and three BssHII fragments (Table 2). Variability in the detection of these fragments in DNA samples from different cells (data not shown) indicates that these multiple bands are due to incomplete methylation at restriction sites. NotI partial digest fragments detected by pCS1 and cCI11-469 are also detected by cCI11-555 (D11S724), the most proximal locus in the next (J1-9) hybrid interval. Thus, the $11 \mathrm{p} 15$ breakpoint in J1-9 is between

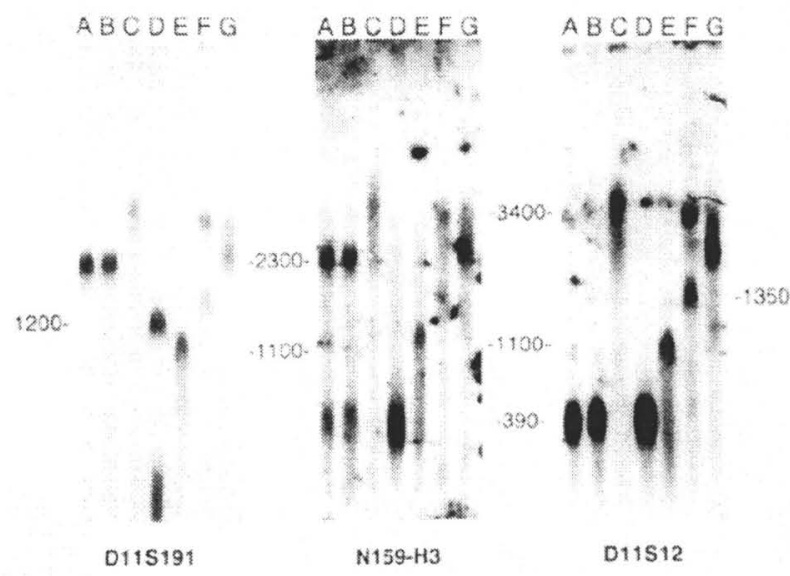

FIG. 4. Long-range restriction mapping of loci in the J1-1/48 to J1-7/43a interval. NotI (lane A), AscI (lane B), BssHII (lane C), SgrAI (lane D), MluI (lane E), and NruI (lane F) digests of GM07048 were separated in a one-dimensional PFGE system (see Materials and Methods), transferred to GeneScreen Plus, and hybridized with probes for the indicated loci. The NotI-linking cosmid N159-H3 detected both the $2300-\mathrm{kb}$ NotI fragment containing D11S191. and the $390-\mathrm{kb}$ NotI fragment detected by pADJ762 (D11S12). Sizes are in kilobases. 
D11S1/D11S679 and D11S724. These three loci were also physically linked to each other and to D11S648, exon 34C, D11S895, D11S193, D11S601, and D11S890 through two adjacent AscI fragments (Fig. 2C).

The J1-9 interval. The most telomeric region defined by the J1-hybrids was shown to contain several genes, including HRAS, INS, IGF2, TH, CTSD, and H19 (Glaser et al., 1989). Three additional genes, MUC2, DRD4, and RNH, have now been mapped to this interval (Fig. 1). Analysis of overlapping clones has shown that IFG2 and INS are less than $13 \mathrm{~kb}$ apart (Bell et al., 1985), and linkage analysis has placed TH very close to these loci (Moss et al., 1986; Xue et al., 1988). Not surprisingly, probes for each of these loci detected exactly the same set of restriction fragments, including a 25-kb BssHII fragment (Table 2). A probe for CTSD detected two AscI fragments and three MluI fragments in common with IGF2 but was found to be on a different NotI fragment (Table 2). Probes for the H19 gene detected the same NotI fragments as IGF2/ INS/TH but SgrAI and NruI fragments in common with CTSD, indicating that H19 is between IGF2 and CTSD. The orientation of these three loci was determined by the analysis of $\mathrm{NruI}$ partial-digest fragments, which demonstrated physical linkage of IGF2 to the more proximal marker D11S1. Since NruI was the only enzyme that connected IGF2 with D11S1, multiple DNA samples were examined to eliminate the possibility that D11S1 and IGF2 are contained on different comigrating fragments. pCS1 (D11S1) detected 680- and $1060-\mathrm{kb}$ NruI fragments with relative intensities that varied among DNA samples (Fig. 5). phins311 (IGF2) detected 380- and 1060-kb fragments with the same variability in intensity. Furthermore, since the combined length of the two smaller NruI fragments ( 380 +680 ) is the same as that of the common partial digest products, these results prove that the $1060-\mathrm{kb}$ fragment detected by D11S1 and IGF2 probes is the same. A similar experiment was carried out to confirm the linkage of H19 and CTSD through 480- and 650-kb NruI fragments (Fig. 5 and data not shown). The order of the four loci used in this analysis is therefore cenD11S1-IGF2-H19-CTSD-tel.

Linkage analysis has shown that HRAS is distal to TH/INS/IGF2 (Moss et al., 1986; O'Rahilly et al., 1992). We have previously demonstrated close physical linkage of the RNH gene to HRAS (Schneider et al., 1992). A radiation hybrid, which was found to be positive for HRAS, RNH, and a putative telomere probe (Cheng et al., 1989) but negative for CTSD, H19, IGF2, and more centromeric $11 \mathrm{p} 15$ loci, allowed the subdivision of the remaining J1-9 positive loci (Fig. 1) into two groups. Cosmid 12A, DRD4, N83, cDNA49C, and cCI11-330 (D11S483) were also contained in this hybrid (unpublished result), grouping them with HRAS and RNH at the telomeric end of J1-9. On the other hand, coincidence clone CK16, NotI-linking cosmid N149-A6, and MUC2 were not contained in this hybrid and are there-
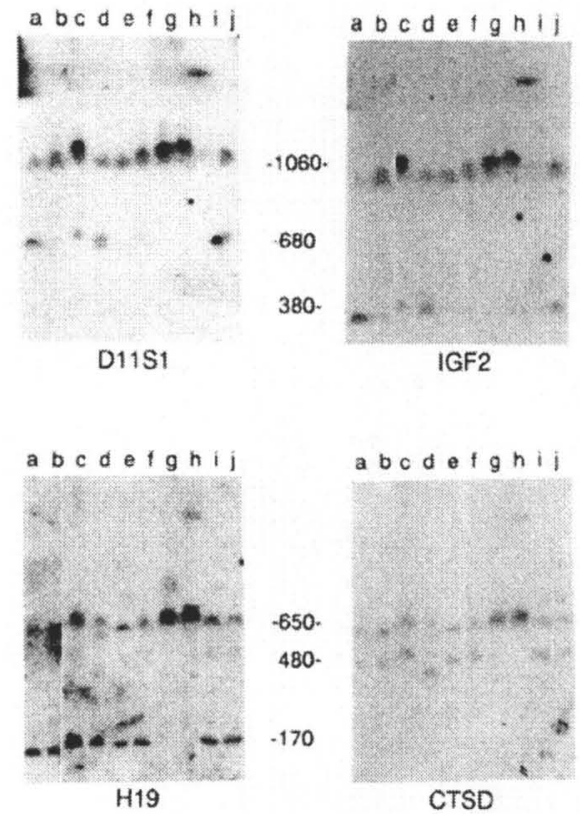

FIG. 5. Orientation of IGF2, H19, and CTSD by NruI site methylation analysis. DNA from 10 cell lines was digested with $\mathrm{NruI}$ and electrophoresed in CHEF gels using switching times of 120 and 180 $\mathrm{s}$ (D11S1 and IGF2) or 60 and $100 \mathrm{~s}$ (H19 and CTSD). Of the three loci known to be positive in J1.9 (IGF2, H19, CTSD), only IGF2 was physically linked to the more centromeric locus D11S1. The 1060-kb partial NruI fragments detected by probes corresponding to D11S1 and IGF2 are the same. This conclusion is based on the similarity in the size of the partial digest fragment with the sum of the two smaller complete digest fragments $(380+680 \mathrm{~kb})$ and consistency in the relative intensities of the complete and partial digests among different DNA samples $(\mathbf{a}-\mathbf{j})$. Since H19 and CTSD lie on none of the three $\mathrm{NruI}$ fragments carrying D11S1 and IGF2, these two genes are telomeric to IGF2. DNA samples were from GM07048(a), GM06419 (b), GM01484 (c), GM02718 (d), GM02971 (e), GM04250 (f), RD (g), AG73 (h), A204 (i), and LiDa (j). Sizes are in kilobases.

fore located between CTSD and the more telomeric cluster of loci. cCI11-330, N83, and cDNA49C detected a 350-kb NruI fragment in common with RNH, locating these three loci on the same side of HRAS as RNH (Table 2, Fig. 2D). The MluI restriction pattern confirmed the physical linkage and suggests that D11S483 and cDNA49C are the farthest markers in this group from HRAS. This interpretation was supported by the finding of a 630-kb ClaI fragment (not included in Table 2) in common among MUC2, HRAS, RNH, and N83 but not D11S483 and cDNA49C (Fig. 2D). Furthermore, since MUC2 is proximal to these loci, this result positions D11S483 and cDNA49C as the most telomeric loci in the map (Fig. 2D), a conclusion supported by interphase FISH (results not shown).

Since DRD4 and c12A are also contained within the 630-kb ClaI fragment but are not present on the MluI and NruI fragments in common with HRAS, RNH, N83, and D11S483, these two loci must be proximal to HRAS. Interphase FISH places c12A proximal to HRAS (not shown), supporting this interpretation. A 
probe for the MUC2 locus hybridized to several NotI fragments, the largest of which is $\mathbf{5 7 0 ~ k b}$. Analysis of NotI digests of several different DNA samples suggests that these multiple fragments are due to incomplete digestion (probably due to restriction site methylation) rather than to cross-hybridization to homologous loci. A $650-\mathrm{kb} \mathrm{AscI} \mathrm{fragment} \mathrm{with} \mathrm{a} \mathrm{partially} \mathrm{cleaved} \mathrm{inter-}$ nal site connected MUC2 with the NotI-linking cosmid N149-A6, which detected two additional NotI fragments of 150 and $200 \mathrm{~kb}$ (Table 2). Finally, one additional Not I fragment of $560 \mathrm{~kb}$ was detected by coincidence clone CK16. This fragment is not identical to the largest fragment containing MUC2 since smaller NotI fragments were not observed and CK16 did not detect any other fragments in common with MUC2 (Table 2). CK16 detected a 1500-kb AscI fragment and large SgrAI, MluI, and $N r u I$ fragments, indicating a minimum separation of $1500 \mathrm{~kb}$ between CTSD and the cluster of linked loci at the telomeric end of the map (Fig. 2D).

\section{DISCUSSION}

We have constructed an ordered NotI fragment map of chromosome band $11 \mathrm{p} 15$. The map consists of 65 loci contained within 39 different NotI fragments with a total length approaching $17 \mathrm{Mb}$. These loci have been ordered within eight intervals defined by J1-deletion hybrids. Cytogenetically, band $11 \mathrm{p} 15$ accounts for approximately one-third of the total length of the short arm of chromosome 11 [ca. $60 \mathrm{Mb}$ (Morton, 1991)]. Thus, the Not I fragments identified in this study constitute $85 \%$ of the estimated $20 \mathrm{Mb}$ of this band.

As well as adding many new markers, the NotI map has refined the order of several genes and anonymous DNA markers within the J1-deletion hybrid intervals (Glaser et al., 1989). The DRD4, MUC2, and RNH genes were assigned to the most telomeric $(J 1-9)$ region originally shown to contain HRAS, INS, IGF, TH, CTSD, and H19. Except for the TH/INS/IGF2 gene cluster, long-range restriction mapping has allowed ordering of these genes (Fig. 2). D11S1 has been positioned telomeric to D11S25 and D11S26 within the next proximal hybrid interval, which were located distal to RRM1. Similarly, D11S30 has been mapped to the same large NotI fragment as HBB but is located distal to this locus. Three new genes have been mapped between HBB and CALCA/PTH with HPX being most telomeric, followed by RBTN1 and then ST5. Tentative physical linkage of CALCA to D11S569 through a single large restriction fragment $(A s c \mathrm{I})$ supports the placement of CALCA telomeric to PTH as determined by mitotic deletion mapping and a recent genetic linkage analysis (Henry et al., 1989; O'Rahilly et al., 1992), which is in contrast to the reverse order determined by earlier genetic linkage studies (Bonaïti-Pellié et al., 1986) and radiation hybrid mapping (Richard et al., 1993). MYOD1 was not included in the initial mapping studies using the J1-hybrids (Glaser et al., 1989) but was more recently mapped proximal to $\mathrm{J} 1-10$ in an interval containing RBTN1, CALCA, and PTH (Henry et al., 1993). In the present study MYOD1 was negative in both J1-8 and J1-37, mapping it centromeric to these genes.

The order of HRAS and DRD4 has also been in question since opposite orientations have been inferred in two different multipoint linkage analyses (Gelernter et al., 1992; Petronis et al., 1993). DRD4 was located proximal to HRAS by both restriction mapping (Fig. 2 ) and interphase FISH. No other discrepancies exist between the order of loci depicted in Fig. 2 and the published genetic linkage and radiation hybrid maps.

Although many physical linkages have been made, a number of discontinuities still exist in the map. The high density of $\mathrm{CpG}$ islands in the region accounts for some of these gaps by reducing the possibility of finding restriction fragments in common between adjacent loci. Assuming that $1 \mathrm{cR}$ is equal to $51 \mathrm{~kb}$, the radiation hybrid map of 11p15 (Richard et al., 1993; James et al., 1994) predicts that the majority of the gaps in the map shown in Fig. 2 are a few hundred kilobases or less. The radiation map does, however, suggest that several megabases may exist between the NotI fragments detected by N30-E10/N155-E5 and D11S569 and between PTH/CALCA and MYOD1 (see Fig. 2A). Additional probes in these regions and partial digest analysis will be necessary to close these gaps in the map.

The Not I map presented in Fig. 2 and the new probes used to construct it should provide useful reagents for the positional cloning of $11 \mathrm{p} 15$ disease-related genes. For example, probes for selected loci on the map have been used in FISH and PFGE analysis to map more precisely three BWS chromosome rearrangements and a rhabdoid tumor translocation between D11S1/ D11S469 and IGF2 (Sait et al., 1994) (see Fig. 2D). It is notable that the mapping of $\mathrm{H} 19$ distal to IGF2 precludes this putative tumor suppressor gene (Hao et al., 1993) from being directly affected by these four rearrangement breakpoints as well as locates this gene outside of the smallest $\mathrm{LOH}$ region determined in breast tumors (Winqvist et al., 1993). In the most telomeric portion of the map, the ordering of several new loci closely linked to HRAS provides additional markers to facilitate the identification of the gene responsible for Long QT syndrome. This map will also provide ordered sets of markers in the vicinity of IGF2 and H19 to help define and characterize an imprinted domain. Finally, in conjunction with the radiation and genetic linkage maps, this map provides many new anchor loci to aid in the construction of clone contigs of $11 \mathrm{p} 15$.

\section{ACKNOWLEDGMENTS}

The following persons kindly provided DNA probes used in this study: L. Maquat, P. Dierks, B. Nelkin, J. Chirgwin, B. Weissman, J. Lichy, F. Altruda, and H. Van Tol. We also thank L. Deaven for the chromosome 11 cosmid library, U. Claussen and B. Horsthemke for the microdissection library, Peter Mayers for computer graphics, 
and Nancy Frame for the excellent preparation of the manuscript. This work has been supported by HG00359.

\section{REFERENCES}

Aleck, K., Williams, J., Mongkolsmai, C., Knight, S., and Taysi, K. (1985). Partial trisomy $11 \mathrm{p}$ with interatrial septal aneurysm: Case report and literature review. Ann. Genet. 28: 102-106.

Bell, G. I., Gerhard, D. S., Fong, N. M., Sanchez-Pescador, R., and Rall, L. B. (1985). Isolation of the human insulin-like growth factor genes: Insulin-like growth factor II and insulin genes are contiguous. Proc. Natl. Acad. Sci. USA 82: 6450-6454.

Boehm, T., Baer, R., Lavenir, I., Forster, A., Waters, J. J., Nacheva, E., and Rabbitts, T. H. (1988). The mechanism of chromosomal translocation $\mathrm{t}(11 ; 14)$ involving the T-cell receptor $\mathrm{C} \gamma$ locus of human chromosome $14 \mathrm{q} 11$ and a transcribed region of chromosome 11p15. EMBO J. 7: 385-394

Bonaïti-Pellié, C., Martinez, M., and Clerget-Darpoux, F. (1986). Multilocus linkage analysis of markers located on the short arm of chromosome 11. Genet. Epidemiol. (Suppl.) 1: 129-134.

Buckler, A., Chang, D. D., Graw, S. L., Brook, J. D., Haber, D. A., Sharp, P. A., and Housman, D. E. (1991). Exon amplification: A strategy to isolate mammalian genes based on RNA splicing. Proc. Natl. Acad. Sci. USA 88: 4005-4009.

Cheng, J.-F., Smith, C. L., and Cantor, C. R. (1989). Isolation and characterization of a human telomere. Nucleic Acids Res. 17:61096127.

Christian, C. L., Liner, R. I., Abu Bak'r, S., McCallum, W. D., and Conte, W. J. (1993). Genomic imprinting and the Beckwith-Wiedemann Syndrome associated with a familial chromosome 11 inversion. Am. J. Hum. Genet. 53: 533.

Coppes, M. J., Bonetta, L., Huang, A., Hoban, P., Chilton-MacNeill, S., Campbell, C. E., Weksberg, R., Yeger, H., Reeve, A. E., and Williams, B. R. G. (1992). Loss of heterozygosity mapping in Wilms' tumor indicates the involvement of three distinct regions and a limited role for nondysjunction or mitotic recombination. Genes Chrom. Cancer 5: 326-334.

Couillin, P., Le Guern, E., Vignal, A., Fizames, C., Ravisé, N., Delportes, D., Reguigne, I., Rosier, M. F., Junien, C., Van Heyningen, V., and Weissenbach, J. (1994). Assignment of 112 microsatellite markers to 23 chromosome 11 subregions delineated by somatic hybrids: Comparison with the genetic map. Genomics 21: 379387.

Davis, L. M., Byers, M. G., Fukushima, Y., Qin, S., Nowak, N. J., Scoggin, C., and Shows, T. B. (1988). Four new DNA markers are assigned to the WAGR region of $11 \mathrm{p} 13$ : Isolation and regional assignment of 112 chromosome 11 anonymous DNA segments. Genomics 3: 264-271.

Dowdy, S. F., Fasching, C. L., Araujo, D., Lai, K.-M., Livanos, E., Weissman, B. E., and Stanbridge, E. J. (1991). Suppression of tumorigenicity in Wilms' tumor by the p15.5-p14 region of chromosome 11. Science 254: 293-295.

Feinberg, A. P., and Vogelstein, B. (1983). A technique for radiolabeling DNA restriction endonuclease fragments to high specific activity. Anal. Biochem. 132: 6-13.

Flejter, W. L., Barcroft, C. L., Guo, S.-W., Lynch, E. D., Boehnke, M., Chandrasekharappa, S., Hayes, S., Collins, F. S., Weber, B. L., and Glover, T. W. (1993). Multicolor FISH mapping with AluPCR-amplified YAC clone DNA determines the order of markers in the $\mathrm{BRCA} 1$ region on chromosome $17 \mathrm{q} 12-\mathrm{q} 21$. Genomics 17: 624631.

Gelernter, J., Kennedy, J. L., van Tol, H. H. M., Civelli, O., and Kidd, K. K. (1992). The D4 dopamine receptor (DRD4) maps to distal 11p close to HRAS. Genomics 13: 208-210.

Gessler, M., Hameister, H., Henry, I. L., Junien, C., Brown, T., and Arnold, H. H. (1990). The human MyoD (Myf3) gene maps on the short arm of chromosome 11 but is not associated with the WAGR locus or the region for the Beckwith-Wiedemann syndrome. Hum. Genet. 86: 135-138.

Giannoukakis, N., Deal, C., Paquette, J., Goodyear, C., and Polychronakos, C. (1993). Parental genomic imprinting of the human IGF2 gene. Nature Genet. 4: 98-101.

Glaser, B., Chiu, K. C., Anker, R., Nestorowicz, A., Landau, H., BenBassat, H., Shlomai, Z., Kaiser, N., Thornton, P. S., Stanley, C. A., Spielman, R. S., Gogolin-Ewens, K., Cerasi, E., Baker, L., Rice, J., Donis-Keller, H., and Permutt, M. A. (1994). Familial hyperinsulinism maps to chromosome $11 \mathrm{pl} 14-15.1,30 \mathrm{cM}$ centromeric to the insulin gene. Nature Genet. 7: 185-188.

Glaser, T., Housman, D., Lewis, W. H., Gerhard, D., and Jones, C. (1989). A fine-structure deletion map of human chromosome 11p: Analysis of $\mathrm{J} 1$ series hybrids. Somatic Cell Mol. Genet. 15: 477501.

Gyapay, G., Morissette, J., Vignal, A., Dib, C., Fizames, C., Millasseau, P., Marc, S., Bernardi, G., Lathrop, M., and Weissenbach, J. (1994). The 1993-94 Généthon human genetic linkage map. $\mathrm{Na}$ ture Genet. 7: 246-339.

Hao, Y., Crenshaw, T., Moulton, T., Newcomb, E., and Tycko, B. (1993). Tumor-suppressor activity of H19 RNA. Nature 365: 764767.

Harrison-Lavoie, K. J., John, R. M., Porteous, D. J., and Little, P. F. R. (1989). A cosmid clone map derived from a small region of human chromosome 11. Genomics 5: 501-509.

Heding, I. J. J. P., Ivens, A. C., Wilson, J., Strivens, M., Gregory, S., Hoovers, J. M. N., Mannens, M., Redeker, B., Porteous, D., Van Heyningen, V., and Little, P. F. R. (1992). The generation of ordered sets of cosmid DNA clones from human chromosome region 11p. Genomics 13: 89-94.

Henry, I., Bonaîti-Pellié, C., Chehensse, V., Beldjord, C., Schwartz, C., Utermann, G., and Junien, C. (1991). Uniparental disomy in a genetic cancer predisposing syndrome. Nature 351: 665-667.

Henry, I., Grandjouan, S., Barichard, F., Huerre-Jeanpierre, C., and Junien, C. (1989). Mitotic deletions of 11 p15.5 in two different tumors indicate that the CALCA locus is distal to the PTH locus. Cytogenet. Cell Genet. 50: 155-157.

Henry, I., Van Heyningen, V., Puech, A., Scrable, H., Augereau, P., Boehma, T., Rabbitts, R., Mannens, M., Rochefort, H., Jones, C., Cavenee, W., and Junien, C. (1993). Reassessment of breakpoints in chromosome 11p15. Cytogenet. Cell Genet. 62: 52-53.

Higgins, M. J., Hansen, M. F., Cavenee, W. K., and Lalande, M. (1989). Molecular detection of chromosomal translocations that disrupt the putative retinoblastoma susceptibility locus. Mol. Cell. Biol. 9: 1-5.

Higgins, M. J., Turmel, C., Noolandi, J., Newmann, P. E., and Lalande, M. (1990). Construction of the physical map for three loci in chromosome band 13q14: Comparison to the genetic map. Proc. Natl. Acad. Sci. USA 87: 3415-3419.

Holmquist, G. P. (1992). Chromosome bands, their chromatin flavors, and their functional features. Am. J. Hum. Genet. 51: 17-37.

James, M. R., Richard, C. W., III, Schott, J.-L., Yousry, C., Clark, K., Bell, J., Hazan, J., Dubay, C., Vignal, A., Agrapart, M., Imai, T., Nakamura, Y., Polymeropoulos, M., Weissenbach, J., Cox, D. R., and Lathrop, G. M. (1994). A radiation hybrid map of 506 STS markers spanning human chromosome 11. Nature Genet., in press.

Julier, C., Hyer, R. N., Davies, J., Merlin, F., Soularue, P., Briant, L., Cathelineau, G., Deschamps, I., Rotter, J. I., Froguel, P., Boltard, C., Bell, J. I., and Lathrop, G. M. (1991). Insulin-IGF2 region on chromosome 11p encodes a gene implicated in HLA-DR4-dependent diabetes susceptibility. Nature 354: 155-159.

Junien, C., and Van Heyningen, V. (1991). Report of the committee on the genetic constitution of chromosome 11. Cytogenet. Cell Genet. 58: 459-554.

Kao, F. T., Jones, C., and Puck, T. T. (1976). Genetics of somatic mammalian cells: Genetic, immunologic and biochemical analysis 
with Chinese hamster cell hybrids containing selected human chromosomes. Proc. Natl. Acad. Sci. USA 73: 193-197.

Keating, M., Atkinson, D., Dunn, C., Timothy, K., Vincent, G. M., and Leppert, M. (1991). Linkage of a cardiac arrhythmia, the long QT syndrome, and the Harvey ras-1 gene. Science 252: 704-706.

Koi, M., Johnson, L. A., Kalikin, Little, P. F. R., Nakamura, Y., and Feinberg, A. P. (1993). Tumor cell growth arrest caused by subchromosomal transferable DNA fragments from chromosome 11. Science 260: 361-364.

Koufos, A., Grundy, P., Morgan, K., Aleck, K. A., Hadro, T., Lampkin, B. C., Kalbakji, A., and Cavenee, W. K. (1989). Familial Wiedemann-Beckwith syndrome and a second Wilms' tumor locus both map to 11p15.5. Am. J. Hum. Genet. 44: 711-719.

Lalande, M., Noolandi, J., Turmel, C., Rousseau, J., and Slater, G. W. (1987). Pulsed-field electrophoresis: Application of a computer model to the separation of large DNA molecules. Proc. Natl. Acad. Sci. USA 84: 8011-8015.

Litt, M., Kramer, P., Hauge, X. Y., Weber, J. L., Wang, Z., Wilkie, P. J., Holt, M. S., Mishra, S., Donis-Keller, H., Warnich, L., Retief, A. E., Jones, C., and Weissenbach, J. (1993). A microsatellite-based index map of human chromosome 11. Hum. Mol. Genet. 2: 909913.

Loh, W. E., Jr., Scrable, H. J., Livanos, E., Arboleda, M. J., Cavenee, W. K., Oshimura, M., and Weissman, B. E. (1992). Human chromosome 11 contains two different growth suppressor genes for em. bryonal rhabdomyosarcoma. Proc. Natl. Acad. Sci. USA 89: 17551759 .

Mannens, M., Hoovers, J. M., Redeker, B., Bliek, J., Feinberg, A. P., Boavida, M., Tommerup, M., Henry, I., Little, P., Leschot, N. J., and Westerveld, A. (1991). Characterization of the region on human chromosome 11p involved in the development of Wilms' tumor associated congenital diseases: A model to study genomic imprinting in man. Eleventh international workshop on human gene mapping, London. Cytogenet. Cell Genet. 58: 1967.

Morton, N. E. (1991). Parameters of the human genome. Proc. Natl. Acad. Sci. USA 88: 7474-7476.

Moss, P. A. H., Davies, K. E., Boni, C., Mallet, J., and Reeders, S. T. (1986). Linkage of tyrosine hydroxylase to four other markers on the short arm of chromosome 11. Nucleic Acids Res. 14: 99279933.

Newsham, I., Claussen, U., Ludecke, H.-J., Mason, M., Senger, G., Horsthemke, B., and Cavenee, W. (1991). Microdissection of chromosome band 11p15.5: Characterization of probes mapping distal to the HBBC locus. Genes Chrom. Cancer 3: 108-116.

NIH/CEPH Collaborative Mapping Group (1992). A comprehensive genetic linkage map of the human genome. Science 258: 67-86.

Norman, A. M., Read, A. P., Clayton-Smith, J., Andrews, T., and Donnai, D. (1992). Recurrent Wiedemann-Beckwith syndrome with inversion of chromosome (11)(p11.2p15.5). Am. J. Med. Genet. 42: 638-641.

Ogawa, O., Becroft, D. M., Morison, I. M., Eccles, M. R., Skeen, J. E, Mauger, D. C., and Reeve, A. E. (1993). Constitutional relaxation of insulin-like growth factor II gene imprinting associated with Wilms' tumor and gigantism. Nature Genet. 5; 408-412.

Ohlsson, R., Nyström, A., Pfeifer-Ohlsson, S., Tröhönen, V., Hedborg, F., Schofield, P., Flam, F., and Ekström, T. J. (1993). IGF2 is parentally imprinted during human embryogenesis and in the Beckwith-Wiedemann syndrome. Nature Genet, 4: 94-97.

O'Rahilly, S., Patel, P., Lehmann, O. J., Tybjaerg-Hansen, A., Nerup, J., Turner, R. C., and Wainscoat, J. S. (1992). Multipoint linkage analysis of the short arm of chromosome 11 in non-insulin dependent diabetes including maturity onset diabetes of youth. Hum. Genet. 89: 207-212.

Petronis, A., Van Tol, H. H. M., Lichter, J. B., Livak, K. J., and Kennedy, J. L. (1993). The D4 dopamine receptor gene maps on 11p proximal to HRAS. Genomics 18: 161-163.

Ping, A. J., Reeve, A. F., Law, D. J., Young, M. R., Boehnke, M., and
Feinberg, A. P. (1989). Genetic linkage of Beckwith-Wiedemann syndrome to 11p15. Am. J. Hum. Genet. 44: 720-723.

Puech, A., Ahnine, L., Ludecke, H. J., Senger, G., Ivens, A., Jeanpierre, C., Little, P., Horsthemke, B., Claussen, U., Jones, C., Junien, C., and Henry, I. (1992). 11p15.5-specific libraries for identification of potential gene sequences involved in Beckwith-Wiedemann syndrome and tumorigenesis. Genomics 13: 1274-1280.

Rainier, S., Johnson, L. A., Dobry, C. J., Ping, A. J., Grundy, P. E., and Feinberg, A. P. (1993). Relaxation of imprinted genes in human cancer. Nature 362: 747-749.

Richard, C. W., III, Boehnke, M., Berg, D., Lichy, J. H., Meeker, T. C., Hauser, E., Myers, R. M., and Cox, D. R. (1993). A radiation hybrid map of the distal short arm of human chromosome 11 containing the Beckwith-Wiedemann and associated embryonal tumor disease loci. Am. J. Hum. Genet. 56: 915-921.

Sait, S. N. J., Nowak, N. J., Singh-Kahlon, P., Weksberg, R., Squire, J., Shows, T. B., and Higgins, M. J. (1994). Localization of Beckwith-Wiedemann and rhabdoid tumor chromosome rearrangements to a defined interval in chromosome band 11p15.5. Genes Chrom. Cancer, in press.

Sanford, J., Kim, B.-W., Deaven, L. L., Jones, C., Higgins, M. J., Nowak, N. J., and Shows, T. B. (1993). A human chromosome 11 NotI end clone library. Genomics 15: 653-658.

Schneider, R., Higgins, M. J., Kieninger, D., Schneider-Scherzer, E., Hirsch-Kauffmann, M., Schweiger, M., Eddy, R. L., Shows, T. B., and Zabel, B. U. (1992). The human ribonuclease/angiogenin inhibitor is encoded by a gene mapped to the chromosome $11 \mathrm{p} 15.5 \mathrm{re}$ gion, within $90 \mathrm{~kb}$ of the HRAS protooncogene. Cytogenet. Cell Genet. 59: 264-267.

Schneider, R., Schneider-Scherzer, E., Thurnher, M., Aner, B., and Schweiger, M. (1988). The primary structure of human ribonuclease/angiogenin inhibitor (RAI) discloses a novel highly diversified protein super family with a common repetitive module. EMBO J. 7: 415-416.

Scrable, H. J., Witte, D. P., Lampkin, B. C., and Cavenee, W. K. (1987). Chromosomal localization of the human rhabdomyosarcoma locus by mitotic recombination mapping. Nature 329: 645647.

Seizinger, B., Klinger, H. P. J., Junien, C., Nakamura, Y., LeBeau, M., Cavenee, W., Emmanuel, B., Ponder, B., Naylor, S., Mittelman, F., Louis, D., Menon, A., Newsham, I., Decker, J., Knelbling, M., Henry, I., and Deimling, A. V. (1991). Report of the committee on chromosome and gene loss in human neoplasia. Cytogenet. Cell Genet. 58: 1080-1096.

Smith, R. J. H., Lee, E. C., Kimberling, W. J., Daiger, S. P., Pelias, M. Z., Keats, B. J. B., Jay, M., Bird, A., Reardon, W., Guest, M., Ayyagari, R., and Hejtmancik, F. (1992). Localization of two genes for Usher Syndrome Type I to chromosome 11. Genomics 14: 9951002.

Takiia, K. I., Tanigami, A., Tokino, T., Jones, C., and Nakamura, Y. (1992). Identification of 57 conventional RFLP and 6 VNTR systems with 32 DNA clones on chromosome 11p15. Genomics 13: 1296-1299

Tanigami, A., Tokino, T., Takiguchi, S., Mori, M., Glaser, T., Park, J. W., Jones, C., and Nakamura, Y. (1992). Mapping of 262 DNA markers into 24 intervals on human chromosome 11. Am. J. Hum. Genet. 50: 56-64.

Tokino, T., Takahashi, E., Mori, M., Tanigama, A., Glaser, T., Park, J. W., Jones, C., Hori, T., and Nakamura, Y. (1991). Isolation and mapping of 62 new RFLP markers on human chromosome 11. Am. J. Hum. Genet. 48: 258-268.

Trask, B. J., Massa, H., Kenwrick, S., and Gitschier, J. (1991). Mapping of human chromosome Xq28 by two-color fluorescence in situ hybridization of DNA sequences to interphase cell nuclei. Am.J. Hum. Genet. 48: 1-15.

Turleau, C., DeGrouchy, J., Chavin-Colin, F., Martelli, H., Vover, M. and Charias, R. (1984). Trisomy $11 \mathrm{p} 15$ and Beckwith-Wiedemann syndrome: A report of two cases. Hum. Genet. 67: 219-221. 
Waziri, M., Paril, S. R., Hanson, J. W., and Bartley, J. A. (1983). Abnormality of chromosome 11 in patients with features of Beckwith-Wiedemann syndrome. J. Pediatr. 102: 873-876.

Weissenbach, J., Gyapay, G., Dib, C., Vignal, A., Morissette, J., Milasseau, P., Vaysseix, G., and Lathrop, M. (1992). A second-generation linkage map of the human genome. Nature 359: 794-801.

Weksberg, R., Teshima, I., Williams, B. R. G., Greenberg, C. R., Pueschel, S. M., Chernos, J. E., Fowlow, S. B., Hoyme, E., Anderson, I. J., Whiteman, D. A. H., Fisher, N., and Squire, J. (1993a). Molecular characterization of cytogenetic alterations associated with the Beckwith-Wiedemann syndrome (BWS) phenotype rewith the Beckwith-Wiedemann syndrome (BWS) phenotype refined the localization and suggest

Hum. Mol. Genet. 2: 549-556.
Weksberg, R., Shen, D. R., Fei, Y. L., Song, Q. L., and Squire, J. (1993b). Disruption of insulin-like growth factor 2 imprinting in Beckwith-Wiedemann syndrome. Nature Genet. 5: 143-149.
Wiedemann, H.-R. (1964). Complexe maliformatif familial avec hernia obilicale et macroglossie. Un "syndrome nouveau"? J. Genet. Hum. 13: 223-225.

Wiedemann, H.-R. (1983). Tumors and hemihypertrophy associated with Wiedemann-Beckwith syndrome. Eur. J. Pediatr. 141: 129.

Winqvist, R., Mannermaa, A., Alavaikko, M., Blanco, G., Taskinen, P. J., Kiviniemi, H., Newsham, I., and Cavenee, W. (1993). Refinement of regional loss of heterozygosity for chromosome 11p15.5 in human breast tumors. Cancer Res. 53: 4486-4488.

Xue, F., Kidd, J. R., Pakstis, A. J., Castiglione, C. M., Mallet, J., and Kidd, K. K. (1988). Tyrosine hydroxylase maps to the short arm of chromosome 11 proximal to the insulin and HRAS1 loci. Genomics 2: $288-293$.

Zhang, Y., and Tycko, B. (1992). Monoallelic expression of the human H19 gene. Nature Genet 1: 40-44. 